\title{
Fragmenty dwóch tkanin z depozytu Muzeum Narodowego w Warszawie znalezionych w kolegiacie w Kruszwicy w 1960 roku
}

Zarys treści: Autorki omawiają dwa zabytki znalezione w trakcie badań archeologicznych w Kruszwicy. Według niej jeden z nich to fragment stuły, a drugi to cingulum.

Abstract: The author writes about two monuments discovered in the course of archaeological excavations in Kruszwica and claims that one is a fragment of a stole, while the other - a cingulum.

Słowa kluczowe: Tekstylia archeologiczne, jedwab, haft średniowieczny, Opus Anglicanum, ryte samitum, szaty liturgiczne, stuła, cingulum, inskrypcje romańskie.

Keywords: archaeological textiles, silk, medieval embroidery, Opus Anglicanum, incised samitum, liturgical vestment, stole, cingulum, Romanesque inscriptions.

\section{Pochodzenie i muzealna historia obiektów}

W 1961 roku Instytut Historii Kultury Materialnej PAN złożył w charakterze depozytu w Muzeum Narodowym w Warszawie pochodzące $\mathrm{z}$ wykopalisk tkaniny określane jako fragmenty dwóch stuł romańskich, z prośbą o ich przechowanie i konserwację. Obiekty przekazano do Działu Tkanin w 1975 r. pod numerami 5232Tc/75/1 i 5232Tc/75/2, które zostały zmienione na Dep. 2741/1 i Dep. 2741 (il. 1) $)^{1}$

Po oczyszczeniu i zabezpieczeniu w latach 70. XX w., tkaniny zostały złożone w dwóch przenośnych kasetach. Badania nad stułami rozpoczęła ówczesna kustosz Działu Tkanin Maria Markiewicz. W pracy skupiła się na analizie formy i symboliki postaci biskupów oraz poszukiwaniu analogii. Podjęła także próbę odczytania napisu² i wyjaśnienie jego genezy i znaczenia ${ }^{3}$. W 2008 r. badania nad

\footnotetext{
${ }^{1}$ Protokół z 28 XI 1977, sporządzony przez kustosz Kolekcji Tkanin Marię Markiewicz, referuje stan obiektów i program prac konserwatorskich: Trzy fragmenty stuły z końca XII wieku zostana zabezpieczone podszyciem siatka, na jedwabiu. Dwa fragmenty umieszczone $w$ gablocie zostana oczyszczone z kurzu i przyczepione do jedwabiu. Jedwab na którym będa podszyte zostanie zwężony o ok. $10 \mathrm{~cm}$ z każdego boku.

${ }^{2}$ W jednej z wersji maszynopisu pracy zachował się list Ewy Springer do M. Markiewicz z dn. 16 V1965. Autorka zamieszcza wstępną opinię na temat haftowanego tekstu prof. Brygidy Kürbis. Litery są romańskie z 1. poł. XII w., napis wierszowany. W związku z obecnością liter (SPE) zwraca uwagę na kult Ducha Św. oraz na niezależność tego tekstu od tekstów liturgicznych.

${ }^{3}$ Obie tkaniny zostały omówione w dwóch rozdziałach nieukończonej pracy doktorskiej poświęconej zachowanym przykładom wczesnośredniowiecznych tkanin liturgicznych w Polsce z Kruszwicy i Tyńca. Fragmenty rozdziałów pracy w kilku redakcjach przechowywane są w archiwum Kolekcji. M. Markiewicz w 1971 roku opublikowała jedynie tekst o stule z Tyńca. M. Markiewicz, Stuła i manipularz z opactwa benedyktynów w Tyńcu pod Krakowem, „Folia Historiae Atrium”, 6/7, 1971, s. 217-238.
} 


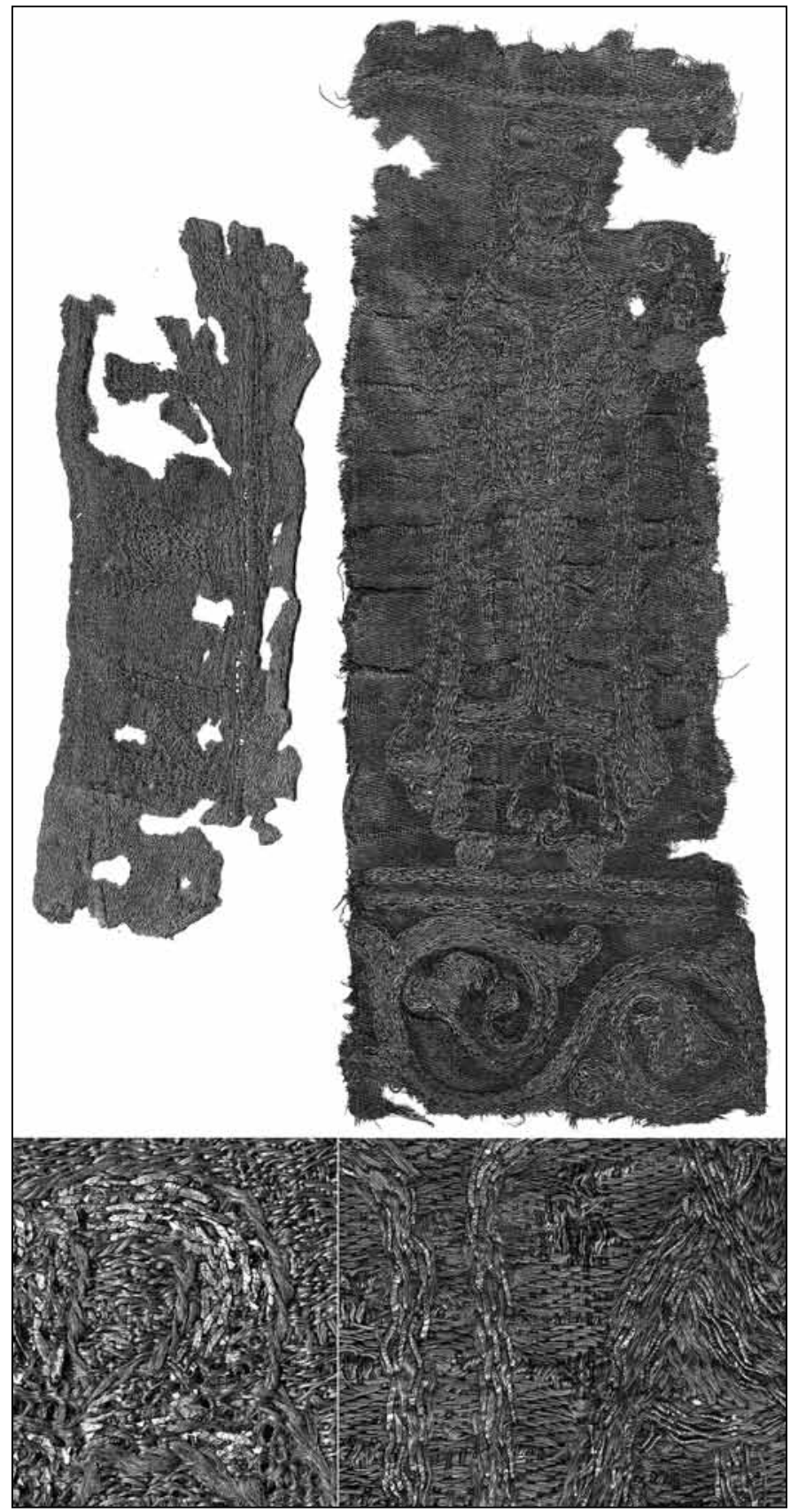

1. Fragmenty tkanin z Kruszwicy: po lewej haft z postaciami biskupów (Dep. 2741/1), po prawej haft z inskrypcjami (Dep. 2741).

Autorstwo wszystkich ilustracji: Maria Cybulska

tkaninami zostały ponownie podjęte. Objęły analizę surowców oraz technik tkackich i hafciarskich. Obie tkaniny zostały zbadane i zwizualizowane $\mathrm{z}$ wykorzystaniem grafiki komputerowej w $2014 \mathrm{r}^{4}$

\footnotetext{
${ }^{4}$ M. Cybulska, E. Orlińska-Mianowska, Analysis, Reconstruction and Interpretation of Two Early Medieval Embroideries from Kruszwica, w: Aspects of the Design, Production and Use of Textiles and Clothing from the Bronze Age to the Early Modern Era. NESAT XII May 2014 in Hallstatt, Austria, red. K. Grömer i F. Pritchard, Archaeolingua, Main Series 33, Budapest 2015, s. 311-320.
} 
Tabela 1. Techniki tkackie i hafciarskie — tkanina z postaciami biskupów

\begin{tabular}{|c|c|c|c|c|}
\hline dep. 2741/1 a-e & $\begin{array}{c}\text { nitki } \\
\text { liczność } / 10 \mathrm{~cm} \\
\end{array}$ & średnica, mm & $\begin{array}{c}\text { kierunek i liczba } \\
\text { skrętów/cm }\end{array}$ & surowiec \\
\hline \multirow{2}{*}{$\begin{array}{l}\text { tkanina splot złożony skośny, } \\
\text { wątkowy (samitum), }\end{array}$} & osnowa zasadnicza 167 × 2 & 0,33 & $\mathrm{Z}, 122$ & jedwab \\
\hline & osnowa wiążąca 167 & $0,19-0,22$ & $\mathrm{Z}, 120$ & jedwab \\
\hline 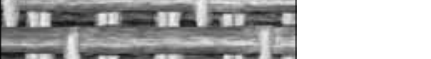 & wątek1 462 & $0,33-0,44$ & bardzo niski & jedwab \\
\hline 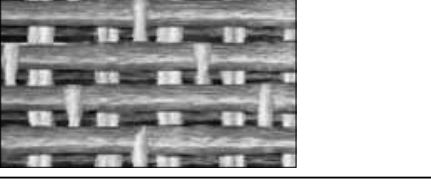 & wątek2 462 & $0,33-0,44$ & bardzo niski & jedwab \\
\hline \multirow{2}{*}{$\begin{array}{l}\text { haft kładziony gubiony, } \\
\text { ściegi rozłupany i sznureczek }\end{array}$} & nitka metalowa & 0,29 & & \\
\hline & oplot & \multicolumn{2}{|c|}{ szerokość blaszki 0,33 , oplot $\mathrm{S}$} & złoto \\
\hline \multirow{4}{*}{ 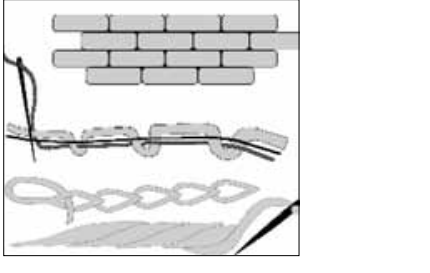 } & rdzeń (dusza) & 0,23 & $\mathrm{Z}$ & jedwab \\
\hline & $\begin{array}{l}\text { nitki haftu atłasowego } \\
\text { i okrętkowego }\end{array}$ & 0,23 & $Z, 60$ & jedwab \\
\hline & $\begin{array}{c}\text { nitka mocująca w hafcie } \\
\text { kładzionym }\end{array}$ & 0,31 & dwojona S2Z, 43 & jedwab \\
\hline & nitka konturów & 0,36 & dwojona S2Z, 49 & jedwab \\
\hline
\end{tabular}

\section{Opis obiektów i analiza techniczna tkanin}

\section{Tkanina z postaciami biskupów}

Tkanina z postaciami biskupów ${ }^{5}$ (Dep. 2741/1 a-e) zachowana jest w pięciu fragmentach, stanowiących dwa końce stuły. Najdłuższy fragment obejmuje zakończenie stuły (szer. 7-8, dł. 71,8 cm) ozdobione skręconą wicią z motywem palmety oraz cztery powtarzające się postaci biskupów o wysokości 14,5-15 cm, rozdzielone podwójnymi paskami o szerokości 3,5 cm. Drugi koniec stuły (szer. $6,8-7, \mathrm{~d}$. $57 \mathrm{~cm}$ ) zachowany jest w czterech mniejszych fragmentach ${ }^{6}$ : największy z palmetą i jedną postacią biskupa (szer. 6,8-7, dl. $22 \mathrm{~cm}$ ) i odspojony, ale będący jego kontynuacją, fragment (szer. 6-7 cm, dł. $18 \mathrm{~cm}$ ) z pojedynczą postacią biskupa, następnie fragment z paskiem rozdzielającym postacie (szer. 1-2, dł. 6,5 cm) i jeszcze jeden fragment z pojedynczą postacią (szer. 6-6,6, dł. $15 \mathrm{~cm}$ ). W sumie zachowało się ok. 128,8 cm tkaniny.

Podkład dla haftu stanowi jedwabna tkanina wykonana w technice samitum (ang. weft-faced compound twill, fr. samit). Nazwą tą określa się średniowieczne tkaniny z dwiema osnowami- zasadniczą i wiążącą oraz z dwoma lub większą liczbą wątków, tkane w splocie złożonym skośnym wątkowym. Haft wykonany jedwabiem i nitką złotą obejmuje szereg różnych technik charakterystycznych dla średniowiecznych haftów, takich jak Opus Anglicanum i hafty bizantyjskie, w tym haft kładziony gubiony

\footnotetext{
${ }^{5}$ Zachowana w dwóch fragmentach leżała po bokach uszkodzonego szkieletu w grobie nr 70, wykopie VII. Zachowały się jedynie jej końcowe partie; część środkowa, umieszczona pod ramionami pochowanego, uległa zniszczeniu. Por. A. Cofta-Broniewska, E. Springer, Wyniki prac terenowych w 1960 roku w Kruszwicy pow. Inowrocław, „Sprawozdania Archeologiczne”, 14, 1962, s. 249-253; E. Springer, Létole de haut Moyen Age trouvée à Kruszwica, „Archeologia Polona”, 6, 1964, s. 338-339; E. Springer, Cmentarzysko szkieletowe na stanowisku 6 w Kruszwicy, Archiwum Instytutu Archeologii i Etnologii PAN.

${ }^{6}$ Porządkując fragmenty stuły założono, że postacie biskupów powinny trzymać pastorały na zewnątrz — postacie po prawej stronie trzymają pastorały w prawej, a postacie po lewej — w lewej ręce.
} 


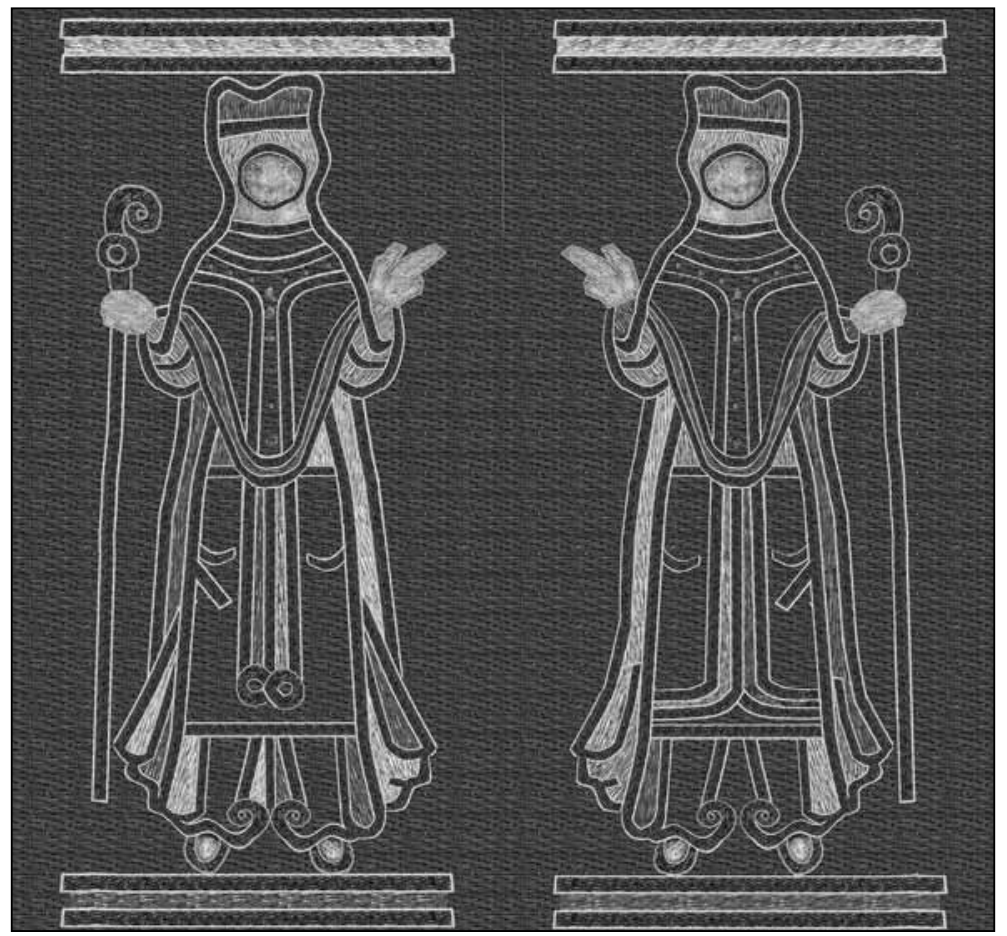

2. Rekonstrukcja haftu na tkaninie z postaciami biskupów. Różnice w detalach ubioru dla postaci z lewego i prawego końca stuły

nitką złotą ${ }^{7}$ oraz ściegi rozłupany i sznureczek. Warto zauważyć, że miejsca haftu przypominające efekt haftu satynowego są najczęściej wykonane techniką mieszaną: część to ścieg kładziony gubiony, część — rozłupany lub sznureczek. Szczegóły dotyczące struktury i materiałów zawiera tabela 1.

Oryginalne kolory to: niebieski dla tkaniny oraz czerwony, różowy, biały i żółty dla haftu. Analiza haftu pozwoliła zauważyć nie tylko różnice $\mathrm{w}$ orientacji postaci, ale także $\mathrm{w}$ detalach ich ubiorów $(\text { il. } 2)^{8}$.

\section{Tkanina $\mathrm{z}$ napisem}

Drugi z obiektów (Dep. 2741/ 2 a-c) to zachowana w trzech fragmentach haftowana tkanina, stanowiąca niegdyś część paramentu. Są to trzy jedwabne pasy o szerokości 4,5 cm i łącznej długości około $1 \mathrm{~m}$ i $35 \mathrm{~cm}$, w całości pokryte haftowanym napisem. Poszczególne fragmenty mają długość: 70,66 i $6 \mathrm{~cm}$. Wysokość liter to ok. 2,5 cm. Na najdłuższym odcinku można odczytać napis: ISTIS - APTATVR • Q • MENTE (T i E tworzą ligaturę) • DEO • FAMVLANTVR; na drugim krótszym pasie: SACTI $\bullet$ SPE (drobny ubytek tkaniny) ASSIT $・$ NOBIS $・$ GRACIA $・$ AMEN; na najmniejszym fragmencie wyhaftowane są trzy litery IAM. W napisach występują różne kroje litery A (il. 3). Napis otoczony jest ramką haftowaną srebrną złoconą nitką.

Podłożem haftu jest ucięty wzdłuż wątku pas jedwabnej wzorzystej tkaniny, najprawdopodobniej w kolorze żółtym, wykonanej w technice ,rytego” samitum (ang. incised samitum). ${ }^{9}$ Technika ta była popularna

\footnotetext{
7 Technika polega na tym, że nitka mocująca biegnie pod tkaniną, przechodzi na powierzchnię nad nitką kładzioną i zawraca w dokładnie tym samym miejscu, przeciągając nitkę kładzioną na spód tkaniny. Dzięki temu na powierzchni nie widzimy mocowań, a jedynie nitkę kładzioną. Jest to główna technika Opus Anglicanum.

${ }^{8}$ M. Cybulska, E. Orlińska-Mianowska, Analysis, Reconstruction and Interpretation, s. 315-316.

${ }^{9}$ Nazwa wzoru tej jednobarwnej tkaniny, w której wzór powstaje przez zmianę warstw dwóch wątków w tym samym kolorze, pochodzi od wyglądu przypominającego traktowany rylcem metal. Por. J. Becker, D. B. Wagner, Pattern and Loom:
} 


\section{ISTIS.APTATVR:Q'MENE.DEO.FAMVLANTVR AM.SACTI.SPE. ASSIT.NOBIS.GRACIA. SIMEN}

\section{Rekonstrukcja haftowanych napisów}

na przełomie IX/X w. Tkaniny charakteryzowały się drobnymi deseniami, jak w jedwabnej tkaninie, z której uszyty jest purpurowy płaszcz króla Sycylii Rogera II z 1133-/34 r., bądź wielkowzorzystą dekoracją, jak w tkaninie ornatu św. Willigisa z katedry w Moguncji, wykonanej w Syrii ok. 1000 r. ${ }^{10}$ Widoczny delikatny wzór jest prawdopodobnie fragmentem większego motywu, gdyż na szerokości tkaniny podobne układy ornamentów powtarzają się bardzo rzadko. Napis haftowany jest nitką metalową ściegiem kładzionym gubionym, okonturowany czerwoną nitką jedwabną ściegiem rozłupanym (w niektórych miejscach przechodzącym w sznureczek). Szczegóły dotyczące struktury i materiałów zawiera tabela 2.

Tabela 2. Techniki tkackie i hafciarskie — tkanina z napisem

\begin{tabular}{|c|c|c|c|c|}
\hline Dep. $2741 / 2$ a-c & $\begin{array}{c}\text { nitki } \\
\text { liczność } / 10 \mathrm{~cm} \\
\end{array}$ & średnica, mm & $\begin{array}{c}\text { kierunek i liczba } \\
\text { skrętów/cm }\end{array}$ & surowiec \\
\hline \multirow{4}{*}{$\begin{array}{l}\text { tkanina wzorzysta: splot } \\
\text { złożony skośny, wątkowy; } \\
\text { wzór powstaje przez } \\
\text { przechodzenie wątków } 1 \text { i } 2 \\
\text { z awersu na rewers tkaniny } \\
\text { i odwrotnie (rytowane } \\
\text { samitum), }\end{array}$} & osnowa zasadnicza $205 \times 2$ & $2 \times(0,16-0,21)$ & Z, 138 & jedwab \\
\hline & osnowa wiążąca 205 & $0,16-0,22$ & $\mathrm{Z}, 138$ & jedwab \\
\hline & wątek 1495 & $0,17-0,21$ & bardzo niski & jedwab \\
\hline & wątek 2495 & $0,20-0,26$ & bardzo niski & jedwab \\
\hline \multirow{5}{*}{$\begin{array}{l}\text { haft kładziony gubiony, } \\
\text { ściegi rozłupany i okrętkowy }\end{array}$} & nitka metalowa & 0,35 & & \\
\hline & oplot & \multicolumn{2}{|c|}{ szerokość blaszki 0,31 ; oplot $\mathrm{S}$} & $\begin{array}{l}\text { srebro } \\
\text { złocone }\end{array}$ \\
\hline & rdzeń (dusza) & 0,26 & $?$ & jedwab \\
\hline & nitka konturów & 0,36 & $\mathrm{~S} 2 \mathrm{Z}$ & jedwab \\
\hline & $\begin{array}{c}\text { nitka mocująca } \\
\text { w hafcie kładzionym }\end{array}$ & $\mathrm{X}$ & $\mathrm{X}$ & jedwab \\
\hline
\end{tabular}

A Practical Study of the Development of Weaving Techniques in China, Western Asia and Europe, Nordic Institute of Asian Studies, t. 127, 2014, s. 129-130.

${ }^{10}$ R. Schorta, Monochrome Seidengewebe des hohen Mittelalters, Berlin 2001, s. 73 i 263. 


\section{Interpretacja obiektów}

\section{Tkanina z postaciami biskupów}

Zachowane jedwabne samity z 1. poł. XII w. pochodzą w większości z relikwiarzy lub są fragmentami różnego rodzaju paramentów: stuł, manipularzy, kap, dalmatyk ${ }^{11}$. Tkanina haftowana z postaciami biskupów jest interpretowana jako stuła, o czym świadczy sposób ułożenia zachowanych fragmentów względem pogrzebanego ciała. Przedstawienia postaci proroków, świętych i duchownych spotyka się na podobnych obiektach z tego okresu. Przykładem mogą być pochodzące z XII w., tkane z jedwabiu na krosienku tabliczkowym, stuła i manipularz z klasztoru benedyktynów w Tyńcu, przedstawiające postaci duchownych w modlitewnych pozach oraz napisy w języku łacińskim odnoszące się do św. Niniana ${ }^{12}$. Innym przykładem są pochodząca z X wieku stuła św. Cuthberta z katedry w Durham, prezentująca na zachowanych fragmentach postaci dwunastu proroków Starego Testamentu oraz manipularz o podobnej dekoracji z czterema postaciami świętych ${ }^{13}$.

Długość średniowiecznych stuł sięgała nawet $300 \mathrm{~cm}^{14}$. Biorąc pod uwagę wysokość postaci, zakończenia i pasków rozdzielających, na stule znajdowało się prawdopodobnie po sześć postaci z każdej strony i, być może, jakiś rodzaj dekoracji pośrodku. Zachowane fragmenty to zatem mniej niż połowa całego obiektu.

\section{Tkanina $\mathrm{z}$ napisem}

Inskrypcje na tkaninach były w średniowieczu bardzo popularne. Jednym z najstarszych przykładów jest haftowana na rytym samicie poduszka $z$ grobu św. Remigiusza, datowana na VIII/IX w. ${ }^{15}$ Najwspanialsze przykłady to płaszcz koronacyjny króla Rogera II z kuficznymi napisami na dolnym brzegu oraz koronacyjna kapa węgierskiego króla Stefana II, z napisami odnoszącymi się do królewskiej donacji i tekstami interpretującymi przedstawione na niej postaci i sceny. Na ornacie z opactwa św. Piotra w Salzburgu napis umieszczony na dolnym brzegu ornatu dotyczy aktu donacji jako zadośćuczynienia za grzechy ${ }^{16}$. W polskich zbiorach znajduje się ornat św. Jadwigi przedstawiający sceny z życia Maryi Dziewicy i Chrystusa oraz postaci świętych i donatorów, zdobiony licznymi inskrypcjami w języku łacińskim ${ }^{17}$.

Dla ustalenia, jaki rodzaj paramentu reprezentuje tkanina $\mathrm{z}$ napisami, wzięto pod uwagę kilka przesłanek. Tkanina jest cięta wzdłuż wątku i tak też wykonany jest haftowany napis. Gdyby fragment pochodził z kapy lub ornatu, musiałby stanowić fragment ich dolnego brzegu, a temu zaprzecza ułożenie fragmentów wzdłuż szkieletu. Nie jest możliwe, by z tak dużego obiektu jak szata liturgiczna, która, sadząc po zachowanej dekoracji, w pozostałych partiach była zapewne także zdobiona haftem, zachował się jedynie niewielki fragment. $Z$ tego też powodu wydaje się mało prawdopodobne,

\footnotetext{
${ }^{11}$ Wśród najstarszych samitów wykorzystanych w średniowiecznych paramentach są tkaniny pochodzące z VII-VIII wieku z Egiptu, Sasanidzkiego Iranu oraz Bizancjum. Por. R Shorta, Monochrome Seidengewebe.

12 M. Markiewicz, Stuła i manipularz, s. 217-238.

13 St. Cuthbert's Stole, The Tablet, 04.07.1936, s. 8, <http://archive.thetablet.co.uk/article/4th-july-1936/8/st-cuthberts-stole> [dostęp: 29.04.2015]

${ }_{14}$ Tej długości są zachowane stuły z tego okresu i na to także wskazuje ikonografia. Por. J. Braun, Die liturgischen Paramente in Gegenwart und Vergangenheit. Ein Handbuch der Paramentik, Freiburg, I.B. 1924.

${ }_{15}$ V. L. Garver, Girlindis and Alpais: Telling the Lives of two Textile Fabricators in the Carolingian Empire, w: Writing Medieval Women's Lives, red. Ch. N. Goldy, A. Livingstone, wyd. 2. New York 2012, s. 155-172.

${ }^{16}$ K. Von Lerber, A Medieval Bell-Shaped Chasuble from St. Peter in Salzburg, „Journal of the Museum of Fine Arts”, Boston, 4, 1992, s. 27.

17 Sztuka polska przedromańska i romańska do schyłku XIII wieku, red. M. Walicki, Warszawa1968, il. 122 i 123.
} 
by tak luksusową szatę przeznaczono do pochówku. Ze względu na kierunek wykonania haftu na tkaninie oraz szerokość fragmentów odrzucono również hipotezę, że obiekt stanowiła stuła.

Jedna z ilustracji manuskryptu Guillaume Duranda przedstawia cingulum, wąską taśmę, którą duchowni przepasywali się w taliii ${ }^{18}$. Średniowieczne cinguli miały zazwyczaj szerokość 3 do $5 \mathrm{~cm}$ i stanowiły raczej dekorację, niż rzeczywiste wiązanie alby. Temu służyły przymocowane do nich sznureczki lub tasiemki, nazywane funiculi. Cinguli tkano na krosienkach tabliczkowych lub wykonywano je z fragmentów tkanin jedwabnych albo lnianych, najczęściej bogato haftowanych. Te dekorowane za pomocą inskrypcji były popularne i nosiły nazwę zonae literae ${ }^{19}$, jak zachowane cingulum biskupa Witgara z Augsburga, datowane na IX w., które doczekało się licznych opracowań ${ }^{20}$.

Powyższe analogie oraz historyczne i techniczne przesłanki mogą wskazywać z dużym prawdopodobieństwem, że tkanina $\mathrm{z}$ napisami to cingulum $^{21}$.

\section{Podsumowanie}

Obie tkaniny wykazują wiele podobieństw, lecz jednocześnie równie wiele znaczących dla ich interpretacji różnic. W obu zastosowano jedwabny samit jako podkład haftu. W przypadku tkaniny z postaciami biskupów tkanina jest gładka i grubsza niż tkanina z napisami. Ta druga reprezentuje bardzo wysokiej jakości wzorzysty jedwab o większej liczności znacznie cieńszych nitek jedwabnych.

Tkaniny były cięte w różnych kierunkach. Tkanina, z której wykonano stułę, cięta jest po osnowie i w tym też kierunku wykonana została haftowana dekoracja. Jest też niemal dwukrotnie szersza niż cięta i haftowana wzdłuż wątku tkanina z napisem. O ile nie ma wątpliwości co do interpretacji pierwszej tkaniny jako stuły, o tyle w przypadku drugiej taniny problem mógłby być nie tak jednoznaczny do interpretacji, gdyby nie ułożenie fragmentów względem pogrzebanego ciała oraz niewielka liczba ocalałych fragmentów. Gdyby pochodziły one z większego obiektu, jak ornat lub kapa, to choćby ze względu na obecność metalowych nitek haftu, chroniących tekstylia przed biodeterioracją, powinno się zachować znacznie więcej fragmentów pochodzących z obszyć dolnych.

Do dekoracji obu tkanin wykorzystano te same ściegi hafciarskie, charakterystyczne dla Opus Anglicanum: ścieg kładziony gubiony, sznureczek i ścieg rozłupany. Wysoki poziom haftowanych dekoracji i tkanin stanowiących podłoże haftu wskazują, że oba obiekty wykonano najpewniej w profesjonalnej pracowni. Kunszt wykonania i szlachetne materiały — jedwab, złoto, srebro złocone świadczą też o wysokiej pozycji w hierarchii kościelnej pochowanych w obu grobach duchownych. Mimo że każda $\mathrm{z}$ tkanin odnaleziona została w innym grobie, wizualizacja ilustrująca interpretację obiektów wykonana została na jednym fantomie (il. 4). Pozwala to lepiej zobrazować różnice między nimi i łatwiej zrozumieć różną ich interpretację.

\footnotetext{
${ }^{18}$ Guillaume Durand, Rationale divinorum officiorum, French translation [Rational des divins offices] by Jean Golein, 1374, fol. 44, gallica.bnf.fr / Bibliotheque National de France, <http://gallica.bnf.fr/ark:/12148/btvlb84497182> [dostęp: 4.02.2014] 19 A. J. Nowowiejski, Wykład liturgii Kościoła Katolickiego 1893, s. 171-172, <http://www.nowowiejski.cba.pl/> [dostęp: 6.03.2014]

${ }^{20}$ Cingulum biskupa Witgara to czerwony haft na białym jedwabiu z napisem Hanc zonam regina nitens sanctissima Hemma Witgario tribuit sacro spiramine plenum (Najjaśniejsza i najświętsza królowa Emma podarowała ten pas Witgarowi przepełnionemu świętym tchnieniem (Duchem Św.), tłum. z angielskiego przekładu Goldberga) odnoszącym się do królowej Emmy, donatorki i obdarowanego biskupa Witgara. Por. E. J. Goldberg, Regina nitens sanctissima Hemma: Queen Emma (827-876), Bishop Witgar of Augsburg, and the Witgar-Belt, w: Representations of Power in Medieval Germany 800-1500, red. B. Weiller, S. MacLean, Turnhout 2006, s. 57-95 oraz S. Müller-Christensen, Textilien [katalog], w: Suevia Sacra: Frühe Kunst in Schwaben, red. B. Bushart, Augsburg 1973, s. 192.

${ }^{21}$ M. Cybulska, E. Orlińska-Mianowska, Analysis, Reconstruction and Interpretation, s. 317-318.
} 


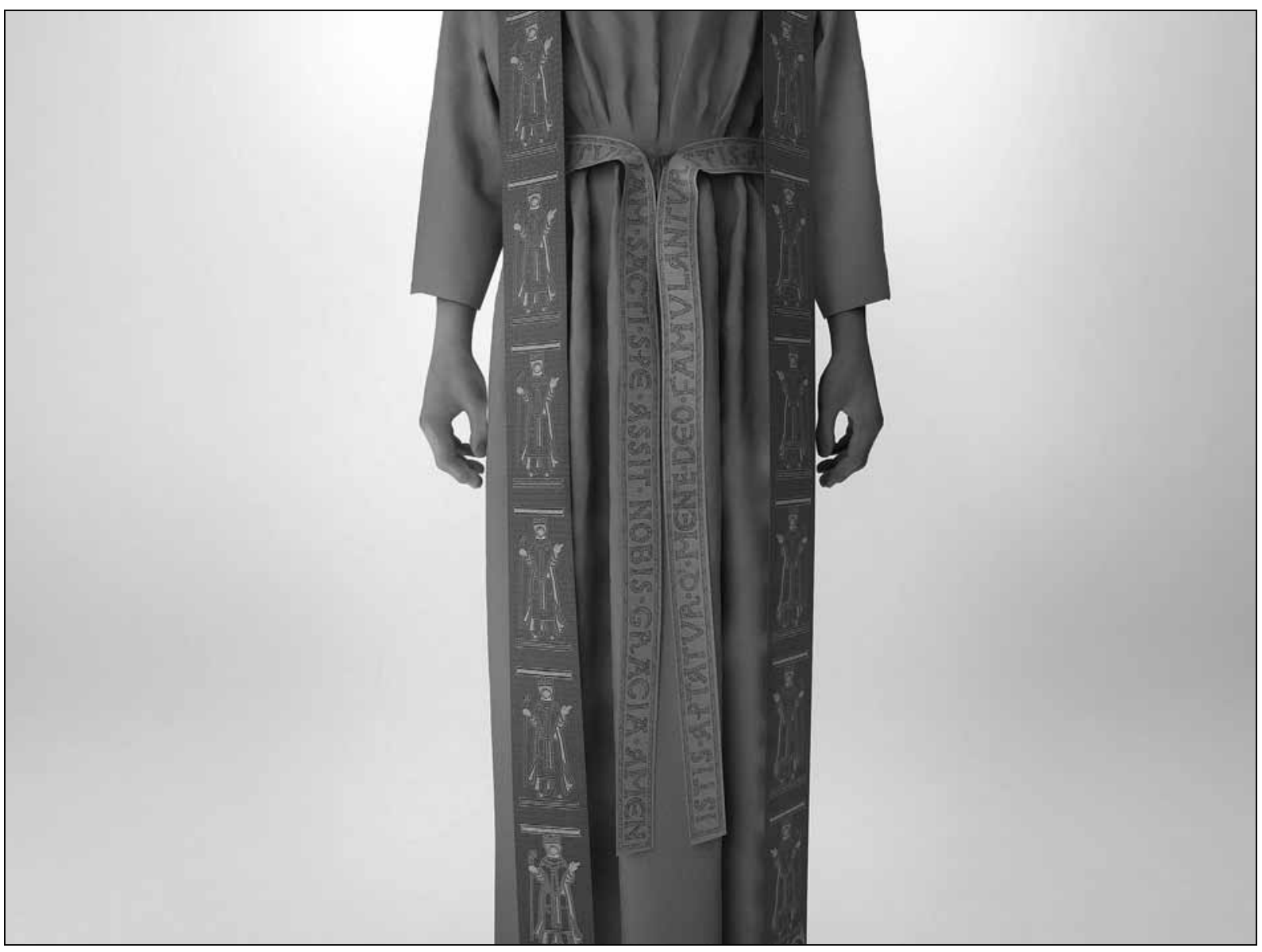

4. Wizualizacja stuły i cingulum

\section{Fragments of Two Fabric Strips from a Deposit at the National Museum in Warsaw Discovered in the Collegiate Church in Kruszwica in 1960}

Summary: This study concerns two objects discovered in 1960 in the course of excavations conducted in the collegiate church of St. Peter and St. Paul in Kruszwica. The findings in question involve embroidery in silk and metal threads on plain and incised satinum. One of the pieces of embroidery shows the figures of bishops, and the other - Latin inscriptions. An analysis of the weaving and embroidery material and techniques as well as a comparative analysis of similar objects from the same period made it possible to formulate a hypothesis about their origin and significance: the first is a fragment of a stole, and the second is a cingulum.

Nota o autorze: Maria Cybuls k a jest kierownikiem pracowni tekstyliów zabytkowych w Instytucie Architektury Tekstyliów Politechniki Łódzkiej. Obszar pracy naukowej obejmuje tekstylia zabytkowe i archeologiczne, w tym historię wzornictwa i technik wytwarzania oraz metody analizy, dokumentacji i rekonstrukcji, z wykorzystaniem nowoczesnych metod analitycznych, grafiki komputerowej oraz technik włókienniczych.

Instytut Architektury Tekstyliów, Politechnika Łódzka, 90-924 Łódź, ul. Żeromskiego 116

e-mail: maria.cybulska@p.lodz.pl

Ewa Orlińska-Mi a now ska jest kustoszem kolekcji tkanin Muzeum Narodowego w Warszawie. Jest autorką książek, katalogów i publikacji naukowych poświęconych, m.in., ubiorom, tkaninom, haftom. Zajmuje się również badaniami na dawnymi technologiami włókienniczymi.

Muzeum Narodowe w Warszawie, Al. Jerozolimskie 3, 00-495 Warszawa

e-mail: EMianowska@mnw.art.pl 
Author: Maria Cybu1ska is in charge of the laboratory of historical textiles in the Institute of Architecture of Textiles, Lodz University of Technology. The area of scientific interest includes historical and archaeological textiles, with emphasis on the history of design and manufacturing techniques, and methods of analysis, documentation and reconstruction of textiles, using modern analytical methods, computer graphics and textile techniques.

Instytut Architektury Tekstyliów, Politechnika Łódzka, 90-924 Łódź, ul. Żeromskiego 116

e-mail: maria.cybulska@p.lodz.pl

Ewa Orlińska-Mianowska is the curator of the textile collection of the National Museum in Warsaw. She is the author of books, catalogues and academic publications related to, among others, costume, woven textiles, embroidery and dyeing. She is also involved in research on historic textile technologies.

Muzeum Narodowe w Warszawie, Al. Jerozolimskie 3, 00-495 Warszawa

e-mail: EMianowska@mnw.art.pl

\section{Bibliografia}

Becker J., Wagner D. B., Pattern and Loom: A Practical Study of the Development of Weaving Techniques in China, Western Asia and Europe, Nordic Institute of Asian Studies, t. 127, 2014

Braun J., Die liturgischen Paramente in Gegenwart und Vergangenheit. Ein Handbuch der Paramentik, Freiburg, I.B. 1924

Cofta-Broniewska A., Springer E., Wyniki prac terenowych w 1960 roku w Kruszwicy pow. Inowrocław, „Sprawozdania Archeologiczne", 14, 1962, s. 249-253

Cybulska M., Orlińska-Mianowska E., Analysis, Reconstruction and Interpretation of Two Early Medieval Embroideries from Kruszwica, w: Aspects of the Design, Production and Use of Textiles and Clothing from the Bronze Age to the Early Modern Era. NESAT XII May 2014 in Hallstatt, Austria, red. K. Grömer i F. Pritchard, Archaeolingua, Main Series 33, Budapest 2015, s. 311-320

Durand G., Rationale divinorum officiorum, French translation [Rational des divins offices] by Jean Golein, 1374, fol.44, gallica.bnf.fr / Bibliotheque National de France, <http://gallica.bnf.fr/ark:/12148/btvlb84497182> [dostęp: 4.02.2014]

Garver V. L., Girlindis and Alpais: Telling the Lives of two Textile Fabricators in the Carolingian Empire, w: Writing Medieval Women's Lives, red. Ch. N. Goldy, A. Livingstone, wyd. 2. New York 2012, s. 155-172.

Goldberg E. J., Regina nitens sanctissima Hemma: Queen Emma (827-876), Bishop Witgar of Augsburg, and the Witgar-Belt, w: Representations of Power in Medieval Germany 800-1500, red. B. Weiller, S. MacLean, Turnhout 2006, s. 57-95

Markiewicz M., Stuła i manipularz z opactwa benedyktynów w Tyńcu pod Krakowem, „Folia Historiae Atrium”, 6/7, 1971, s. 217-238

Müller-Christensen S., Textilien [katalog], w: Suevia Sacra: Frühe Kunst in Schwaben, red. B. Bushart, Augsburg 1973, s. 192

Nowowiejski A. J., Wykład liturgii Kościoła Katolickiego, 1893, <http://www.nowowiejski.cba.pl/> [dostęp: 6.03.2014]

Schorta R., Monochrome Seidengewebe des hohen Mittelalters, Berlin 2001

Springer E., L'étole de haut Moyen Age trouvée à Kruszwica, „Archeologia Polona”, 6, 1964, s. 338-339

Springer E., Cmentarzysko szkieletowe na stanowisku 6 w Kruszwicy, Archiwum Instytutu Archeologii i Etnologii PAN

Von Lerber K., A Medieval Bell-Shaped Chasuble from St. Peter in Salzburg, „Journal of the Museum of Fine Arts", 4, Boston 1992, s. 27-51

St. Cuthbert's Stole, „The Tablet”, 04.07.1936, s. 8, <http://archive.thetablet.co.uk/article/4th-july-1936/8/ st-cuthberts-stole> [dostęp: 29.04.2015]

Sztuka polska przedromańska i romańska do schytku XIII wieku, red. M. Walicki, Warszawa1968, il. 122 i 123 